PIMENTA, S; RODRIGUES, R; SUDRÉ, CP; MORAES, JGT; BENTO, CS; MEDEIROS, AM. 2016. Protecting vegetable cultivars in Brazil: a chili pepper case-study research. Horticultura Brasileira 34: 161-167. DOI - http://dx.doi.org/10.1590/S0102-053620160000200003

\title{
Protecting vegetable cultivars in Brazil: a chili pepper case-study research
}

Samy Pimenta; Rosana Rodrigues; Cláudia P Sudré; João GT Moraes; Cíntia S Bento; Artur M Medeiros Universidade Estadual do Norte Fluminense Darcy Ribeiro (UENF), Campos dos Goytacazes-RJ, Brasil; pimentasamy@gmail.com; rosana@uenf.br; cpombo@uenf.br; jgtmoraes@hotmail.com; cintia_bento@yahoo.com.br; arturmedeiros_eln@hotmail.com

\begin{abstract}
In all countries, members of the UPOV (Union Internationale pour la Protection des Obtentions Végétales), of which Brazil is a signatory, to protect a new plant variety is necessary to carry out DUS (Distinctness, Uniformity and Stability) tests. DUS testing for Capsicum spp. is based on 48 descriptors, which involve qualitative and quantitative traits, observed from germination to fruit harvest. This paper describes the performance of DUS tests on lines of chili peppers, which are candidates for protection; we discuss the main aspects related to operational difficulties, the relevance of some descriptors for the protection process and highlight the importance of protecting new plant varieties as national intellectual property. Four C. annuиm var. annuиm recombinant inbred lines were tested. The Capsicum Breeding Program of the Universidade Estadual do Norte Fluminense Darcy Ribeiro developed the lines, which are resistant to bacterial spot. They were tested under greenhouse conditions from June to November 2013; and from January to July 2014 in Campos dos Goytacazes, Rio de Janeiro State, Brazil. The 'Jalapeño $\mathrm{M}^{\prime}$ ' commercial genotype was used as control and treatments were arranged in a randomized block design with seven plants per plot with five replications. Besides the 48 descriptors, stipulated by legislation for Capsicum DUS testing, we included a descriptor for bacterial spot resistance. The descriptors that enabled distinction varied with each line. Although being distinctive for some descriptors, L1 and L2 lines were neither homogeneous nor stable. L6 and L8 recombined lines were characterized by homogeneity and stability. Fruit shape, capsaicin presence, number of days for flowering and bacterial spot resistance were descriptors that allowed for differentiation between treatments. In conclusion, the L6 and L8 recombined lines met the DUS test requirements; therefore, they may be subjected to the protection process with the Brazilian Ministry of Agriculture, Livestock and Food Supply.
\end{abstract}

Keywords: Capsicum annuum, intellectual property, DUS test, bacterial spot resistance, agribusiness innovation.

\section{RESUMO}

Proteção de cultivares de hortaliças no Brasil: um estudo do caso com pimenta

Em todos os países, membros da UPOV (Union Internationale pour la Protection des Obtentions Végétales), da qual o Brasil é signatário, para que uma nova cultivar tenha sua proteção efetivada, é necessária a realização de testes de DHE (Distinguibilidade, Homogeneidade e Estabilidade). O teste de DHE para Capsicum spp. é baseado em 48 descritores, envolvendo caracteres qualitativos e quantitativos, observados desde a germinação até a colheita dos frutos. Neste trabalho descreve-se a execução de ensaios de DHE com linhagens de pimentas, candidatas à proteção, discutem-se os principais aspectos relacionados às dificuldades operacionais, a relevância de alguns descritores para o processo de proteção e aborda-se a importância da proteção de cultivares como propriedade intelectual para o País. Quatro linhagens de C. annuиm var. annuum resistentes à mancha bacteriana desenvolvidas pelo Programa de Melhoramento Genético de Capsicum da Universidade Estadual do Norte Fluminense Darcy Ribeiro foram testadas em casa de vegetação nos períodos de junho a novembro de 2013 e janeiro a julho de 2014, em Campos dos Goytacazes-RJ. A cultivar Jalapeño M foi utilizada como testemunha. Os tratamentos foram distribuídos em delineamento de blocos ao acaso, com cinco repetições e sete plantas por parcela. Além dos 48 descritores estipulados pela legislação para o DHE em Capsicum, incluiu-se um descritor para a resistência à mancha bacteriana. Os descritores que permitiram a distinção variaram para cada linhagem. Apesar de serem distintas em alguns descritores, as linhagens L1 e L2 não foram homogêneas e estáveis. As linhagens L6 e L8 se caracterizaram pela homogeneidade e estabilidade. Entre os descritores que permitiram a distinção entre os tratamentos estão o formato do fruto, a presença de capsaicina, o número de dias até o florescimento e a resistência à mancha bacteriana. Ao fim, as linhagens L6 e L8 atenderam às exigências de DHE e poderão ser submetidas ao processo de proteção junto ao Ministério da Agricultura, Pecuária e Abastecimento.

Palavras-chave: Capsicum annuиm, propriedade intelectual, ensaios de DHE, resistência à mancha bacteriana, inovação no agronegócio.

\section{(Recebido em 9 de fevereiro de 2015; aceito em 21 de setembro de 2015)} (Received on February 9, 2015; accepted on September 21, 2015)

$\mathrm{D}$ ifferent mechanisms for plant variety protection (PVP) regimes are adopted worldwide and countries may use their own legislation to protect varieties by patent or sui generis system or even a mixed system with a combination of both (Araújo, 2010; Viana, 2011).
Most countries, including Brazil, do not adopt the patent system for plant protection. Sui generis is the system used in Brazil to protect new plant 
varieties (Aviani \& Machado, 2011). This protection is ensured by a domestic law known as The Plant Protection Law (LPC) no. 9,456 of April of 1997 (Brazil, 1997), being established in accordance with the guidelines of the Union Internationale pour la Protection des Obtentions Végétales (UPOV). Countries that are signatory to the UPOV shall ensure, in their national legislation, the adoption of the UPOV Act into force, allowing members to use the same basic principles, sharing technologies, standardization, reciprocation, training and exchange, which will result in various benefits among members (Araújo, 2010; Santos et al., 2012; Leite \& Munoz, 2013).

The above-mentioned law allows breeders' compensation and for the promotion of research and development, which ultimately increases crop production and conservation of genetic resources (ISF, 2012). In this sense, an effective PVP system is essential for plant breeding programs, generating incentives for breeders and a return on investments (Greengrass, 2004).

For effective protection of a new variety, five requirements are needed: innovation, distinctiveness, uniformity, stability and own denomination, which are common requirements of the members of UPOV (Brazil, 1997; UPOV, 2002), and additionally to comply with other legal formalities (Machado, 2011). In Brazil, DUS tests are the responsibility of the applicant and results must be submitted to the Ministério da Agricultura, Pecuária e Abastecimento (MAPA) together with the application for protection. Furthermore, it is only possible to perform DUS testing for species with morphological descriptors published in the Diário Oficial (Official Gazette) (Brasil, 1997; Carvalho et al., 2009; Aviani \& Machado, 2011).

DUS testing guidelines for protectable plant species are drawn up by an expert group composed of nominees from each member of UPOV, foreign experts and observer organizations (UPOV, 2002) experts. Once published, it becomes the basis for national guidelines. In Brazil, the guidelines are discussed jointly by the National Service for Plant Variety Protection (Serviço Nacional de Proteção de Cultivares, SNPC), responsible for applications, and researchers to adapt them to the Brazilian context (Machado, 2011). After publication in the Diário Oficial (Official Gazette), the guidelines are disseminated and become available to interested parties. Guidelines for 121 plant species were published in Brazil up to 2012 (Santos et al., 2012).

For Capsicum, DUS testing is based on 48 binary and multicategoric descriptors including qualitative and quantitative traits, which are evaluated from germination to fructification (Brazil, 2006). Other descriptors can be added to the required ones, since the aim is to differentiate better between candidate varieties. For that, a great example would be those descriptors related to pest and disease resistance (Lovato, 2011).

The PVP contributes significantly to the technological and economic development of the country, changing the technology generation model in current seed production (Viana, 2011). This contribution is most significant when it comes to self-pollinated species, since any seed producer can obtain seeds from its own crop for several generations. If there were no PVP system, a direct consequence would be the restriction of autogamous species breeding programs to public institutions (Araújo, 2010). In soybean, for instance, most of the Brazilian breeding programs started after the LPC (Ramalho et al., 2010).

This paper describes DUS tests with recombinant lines of chili peppers that are protection candidates. The main aspects related to operational difficulties, descriptor relevance for the protection process and highlight the importance of plant protection as a national intellectual property are discussed.

\section{MATERIAL AND METHODS}

The C. annuum var. annuum genotypes used were four recombined lines labeled L1, L2, L6 and L8, protection candidates, and a commercial genotype named 'Jalapeño M' (Topseed).
Lines were obtained from the Capsicum Breeding Program of the UENF by SSD (Single Seed Descent) method. Such genotypes correspond to the $F_{9}$ generation of crossing between UENF 1421 and UENF 1381 accessions. The first is susceptible to bacterial spot, with yield and fruit quality traits that meet chili pepper market standards. The second is the source of disease resistance, whose genetic control is due to three recessive genes (Riva et al., 2004). After generations of inbreeding via $\mathrm{SSD}$, the recombinant lines were selected for bacterial spot resistance and other attributes (Moreira et al., 2009, 2010).

The DUS tests were carried out in the greenhouses of the Laboratório de Melhoramento Genético Vegetal of the University in Campos dos Goytacazes. The tests were carried out during the periods of June to November 2013 and from January to July 2014. We adopted all recommendations on DUS testing for Capsicum plants proposed by SNPC (Brazil, 2006).

The experimental design used was randomized blocks with seven plants per plot, repeated five times for both trials, totaling 35 plants per treatment. The plants were grown in five-liter pots with substrate containing soil, sand and cattle manure at a ratio of 1:1:1. The space between rows was 1.0 $\mathrm{m}$ and $0.5 \mathrm{~m}$ between plants. The Act no. 2 of 2006 determines that under protected cultivation, each test should use a minimum of 18 plants, divided into two or more replications (Brazil, 2006). Farming practices were followed according to the crop recommendation (Filgueira, 2012).

We evaluated the descriptors (01-48) required by SNPC (Table 1). Capsaicin presence evaluation was performed using a fruit placenta sample (approximately 1 $\mathrm{cm}^{2}$ ), which was immersed in a solution of $3 \mathrm{~mL}$ of ammonium vanadate, during five hours. After this period, the presence of brown spots in the placenta indicated the presence of capsaicin. Additionally, the descriptor for bacterial spot resistance was included, since the breeding program aimed to obtain plants resistant to this disease. For lines description and comparison, we applied 
statistical mode analysis to scores attributed to each genotype, which constitutes the most frequent value within a data set.

For the evaluation of bacterial spot resistance, we prepared an inoculum from isolated colonies of ENA 4135, previously identified as race $T_{1} P_{3}$, according to Jones et al. (1998). Isolate kept in water was recovered, transferring bacterial suspension into Petri dishes with DYGS solid medium (Rodrigues Neto et al., 1986), using a platinum handle. After staying in a bacteriological incubator for $48 \mathrm{~h}$ at $28^{\circ} \mathrm{C}$, bacterial colonies were suspended in distilled and autoclaved water, and its concentration was adjusted to $10^{8} \mathrm{cfu} /$ $\mathrm{mL}$ with the aid of a spectrophotometer at $600 \mathrm{~nm}$ wavelength and absorbance of $0.300\left(\mathrm{~A}_{600}=0.3\right)$ (Quezado-Duval \& Camargo, 2004). Next, we performed a serial dilution up to a concentration of $10^{5} \mathrm{cfu} / \mathrm{mL}$. Inoculation was performed 15 days after transplanting by bacterial suspension infiltration onto the leaf abaxial surface previously identified within an area of almost $1.0 \mathrm{~cm}^{2}$. Response to bacterial spot assessment was carried out on the fifth day after inoculation, through seven observations at one-day intervals, scoring from 1.0 (resistant) to 5.0 (susceptible) for the symptoms over the inoculated area (Riva-Souza et al., 2009). Using the resistance data, we calculated the area under the disease progress curve (AUDPC), according to Campbell \& Madden (1990).

Descriptive technical report filling, which is required to apply for variety protection, requires the comparison of only one plant with control in each report (Brazil, 2006). However, several control treatments are allowed in a DUS test. In this research, the candidate lines were compared with the commercial variety and acted as control when compared to each other.

\section{RESULTS AND DISCUSSION}

There were no differences between lines and the commercial variety used as control in at least 28 out of the 49 descriptors assessed in the two trials
(Table 1). Such descriptors were stem position; short internodes; number of internodes; width, green coloration, variegation, anthocyanin pigmentation of leaves; number of flowers per axilla; corolla coloration; stain on the corolla; anther and filament color; fruit yield and color before ripeness; position, diameter, surface texture, color at maturity, stalk cavity depth, apex shape, depth of interlocular grooves and predominant locule number per fruit; placenta size; peduncle length and thickness; calyx form and constriction; cycle up to ripeness. Two of them, internode length (descriptor no. 6) and corolla spot coloration (descriptor no. 19), could not be evaluated since they were absent in the tested genotypes. Corolla spot is mainly observed in species such as $C$. baccatum and $C$. praetermissum (McLeod et al., 1982).

The lack of differentiation within the 28 traits was expected since specific descriptors for flowers, for example, are most useful for distinguishing between different species; however, in this study all the genotypes belong to $C$. annuиm var. annuиm species. This species flower is characterized by the white color, lack of corolla spots and having one flower per node (Bosland, 1996).

Green coloring of leaves, fruit yield and coloring before and after maturity, for example, may lead to a lack of uniformity and stability when the evaluator is changed within a trial or even from one crop cycle to the next, because it is a subjective analysis related to color viewing, with no use of auxiliary material. Consequently, we must highlight important points for the use of descriptors such as the evaluators' specific experience with the crop, preferably using the same person, in order to ensure scoring standardization. The evaluator in a DUS test should adopt the same standards of precision and repetition used for fulfilling the descriptors in the testing; thus ensuring the reliability of the results (Gilliland \& Gensollen, 2010).

It was not possible to draw a distinction between L1 and 'Jalapeno M' based on 33 out of the 48 descriptors. Some descriptors such as stem length; leaf length; hairiness, and capsaicin in placenta were not homogeneous in the first trial. Nevertheless, for the second trial, the homogeneity was confirmed. It is worth emphasizing that the lack of homogeneity in the first trial generated stability shortage in both trials (Table 1). Homogeneity is ensured by adopting $1 \%$ default and $95 \%$ probability for the occurrence of atypical plants under protected cultivation (Brazil, 2006). Variety stability is attested when the essential traits are maintained over successive cycles. The lack of homogeneity and stability of these descriptors resulted in them not meeting the requirements for the protection of this lineage.

In addition, the lack of homogeneity for the L2 lineage on shape descriptors of fruits in longitudinal and cross section, besides the brightness and capsaicin in the fruit placenta, observing a number above that permitted of atypical plants in the first trial. However, it did not occur in the second trial, in which homogeneity was observed for L2. Nevertheless, considering the mode analysis to classify each descriptor, a lack of stability was not detected in this lineage. The experience of plant variety protection in Brazil has shown that in most cases a homogeneous plant would be stable (Santos \& Machado, 2011), but for this lineage, stability was not related to homogeneity.

Interestingly, the stability test for self-pollinated varieties enables the substantiation of homozygous level and contaminant absence (Brazil, 2006). Possibly, the lack of homogeneity and stability in L1 and L2 may be associated with contamination by mixing seeds, since all lines had high homozygous levels at the $\mathrm{F}_{9}$ generation.

Thirty-one descriptors were identical for genotype L6 compared to control. However, 16 descriptors enabled us to distinguish L6 from to 'Jalapeno M' (Table 1); among these, capsaicin in the fruit placenta can be highlighted (descriptor no. 46), since capsaicin was not found in this lineage of fruits. This descriptor classifies L6 as "sweet" pepper, which can be a product of interest, because not do only pungent peppers please consumers, but there is a niche market for fresh sweet 
Table 1. Capsicum morphological descriptos evaluated in DUS tests, as recommended by the National Service for Plant Variety Protection for the protection of $C$. annuum cultivars (descritores morfológicos de Capsicum avaliados em ensaios de DHE, conforme recomendação do Serviço Nacional de Proteção de Cultivares para a proteção de variedades de C. annuum). Campos dos Goytacazes, UENF, 2014.

\begin{tabular}{|c|c|c|c|c|c|}
\hline \multirow{3}{*}{ Descriptors } & \multirow{3}{*}{$\begin{array}{c}\text { Commercial } \\
\text { genotype } \\
\text { Jalapeño M } \\
1^{\text {st }} \text { test } 2^{\text {nd }} \text { test }\end{array}$} & \multicolumn{4}{|c|}{ Pre-cultivars in test } \\
\hline & & L1 & \multirow{2}{*}{$\frac{\mathrm{L} 2}{1^{\text {st }} \text { test } 2^{\text {nd }} \text { test }}$} & \multirow{2}{*}{$\frac{\text { L6 }}{1^{\text {st }} \text { test } 2^{\text {nd }} \text { test }}$} & \multirow{2}{*}{$\frac{\text { L8 }}{1^{\text {st }} \text { test } 2^{\text {nd }} \text { test }}$} \\
\hline & & $1^{\text {st }}$ test $2^{\text {nd }}$ test & & & \\
\hline Seedling: anthocyanin coloration of hypocotyl & Presence & Absent & Absent & Absent & Absent \\
\hline Plant: position stems & Upright & Upright & Upright & Upright & Upright \\
\hline Plant: length of stem & Medium & Medium Long & Medium & Medium & Medium \\
\hline Plant: shortened internode & Presence & Presence & Presence & Presence & Presence \\
\hline $\begin{array}{l}\text { Plant: number of internodes between the first } \\
\text { flower and shortened internodes }\end{array}$ & $\begin{array}{l}\text { More than } \\
\text { three }\end{array}$ & $\begin{array}{l}\text { More than } \\
\text { three }\end{array}$ & $\begin{array}{c}\text { More than } \\
\text { three }\end{array}$ & $\begin{array}{l}\text { More than } \\
\text { three }\end{array}$ & $\begin{array}{l}\text { More than } \\
\text { three }\end{array}$ \\
\hline Varieties without shortened internodes only & $-\quad \quad-$ & $-\quad \quad-$ & $-\quad \quad-$ & $-\quad \quad-$ & $-\quad \quad-$ \\
\hline Plant: intensity of anthocyanin coloration of nodes & Very strong & Strong & Strong & Strong & Strong \\
\hline Leaf: length of blade & Long & Medium Long & Medium & Medium & Medium \\
\hline Leaf: width of blade & Medium & Medium & Medium & Medium & Medium \\
\hline Leaf: green color & Dark & Dark & Dark & Dark & Dark \\
\hline Leaf: variegation & Absent & Absent & Absent & Absent & Absent \\
\hline Leaf: anthocyanin coloration & Absent & Absent & Absent & Absent & Absent \\
\hline Leaf: hairiness & Absent & Absent Dense & Absent & Medium & Absent \\
\hline Leaf: roughness & Weak & Absent & Absent & Absent & Absent \\
\hline Flower: number of flowers per axil & One & One & One & One & One \\
\hline Flower: peduncle position & Pendant & Inter. & Inter. & Inter. & Inter. \\
\hline Flower: corolla colour & White & White & White & White & White \\
\hline Flower: corolla spot & Absent & Absent & Absent & Absent & Absent \\
\hline Flower: corolla spot colour & $-\quad \quad-$ & $-\quad \quad-$ & $-\quad \quad-$ & $-\quad \quad-$ & $-\quad \quad-$ \\
\hline Flower: anther colour & Blue & Blue & Blue & Blue & Blue \\
\hline Flower: filament colour & White & White & White & White & White \\
\hline Flower: stigma position & Exserted & Inserted $\begin{array}{c}\text { Same } \\
\text { level }\end{array}$ & Inserted & Exserted & Inserted \\
\hline Fruit: color before maturity & Green & Green & Green & Green & Green \\
\hline Fruit: intensity of color before maturity & Dark & Dark & Dark & Dark & Dark \\
\hline Fruit: position & Inter. & Inter. & Inter. & Inter. & Inter. \\
\hline Fruit: length & Medium & Medium Long & Medium & Short & Medium \\
\hline Fruit: diameter & Small & Small & Small & Small & Small \\
\hline Fruit: shape in longitudinal section & Oval & Elliptic $\quad \mathrm{NT}$ & Elliptic & Triang. & Elliptic \\
\hline Fruit: shape in cross section & Rounded & Elliptic Ang. & Elliptic & Ang. & Elliptic \\
\hline Fruit: sinuation of pericarp at basal part & Very weak & Medium & Very weak & Weak & Very weak \\
\hline Fruit: texture of surface & Smooth & Smooth & Smooth & Smooth & Smooth \\
\hline Fruit: color at maturity & Red & Red & Red & Red & Red \\
\hline Fruit: intensity of color at maturity & Medium & Medium & Dark & Dark & Dark \\
\hline Fruit: glossiness & Strong & Strong Weak & Strong & Strong & Strong \\
\hline Fruit: depth of stalk cavity & $\mathrm{A} / \mathrm{VW}$ & A/VW & $\mathrm{A} / \mathrm{VW}$ & A/VW & $\mathrm{A} / \mathrm{VW}$ \\
\hline Fruit: shape of apex & Rounded & Rounded & Rounded & Rounded & Rounded \\
\hline Fruit: depth of interloculary grooves & Medium & Medium & Medium & Medium & Medium \\
\hline Fruit: number of locules & Three and four & Three and four & Three and four & Three and four & Three and four \\
\hline Fruit: thickness of flesh & Thick & Medium Thin & Medium & Thin & Medium \\
\hline Placenta: size & Great & Great & Great & Great & Great \\
\hline Stalk: length & Medium & Medium & Medium & Medium & Medium \\
\hline Stalk: thickness & Medium & Medium & Medium & Medium & Medium \\
\hline Calyx: margin & Jagged & Inter. & Inter. & Jagged & Inter. \\
\hline Calyx: constriction & Presence & Presence & Presence & Presence & Presence \\
\hline Calyx: aspect & Envol. & Envol. & Envol. & Envol. & Envol. \\
\hline Fruit: capsaicin in placenta & Presence & Presence Absent & Presence & Absent & Presence \\
\hline Time of beginning of flowering & Early & Medium & Medium & Medium & Medium \\
\hline Time of maturity & Medium & Medium & Medium & Medium & Medium \\
\hline Reaction to bacterial spot & $\mathrm{S}$ & $\mathrm{R}$ & $\mathrm{R}$ & $\mathrm{R}$ & $\mathrm{R}$ \\
\hline
\end{tabular}

Inter.= intermediate (intermediária); NT= narrowly triangular (estreito triangular); Triang= triangular (triangular); Ang= angled (angulada); $\mathrm{A} / \mathrm{VW}=$ very weak or absent (ausente ou muito fraca); Envol.= enveloping (envolvente); $\mathrm{S}=$ susceptible (suscetível); $\mathrm{R}=$ resistant (resistente). 


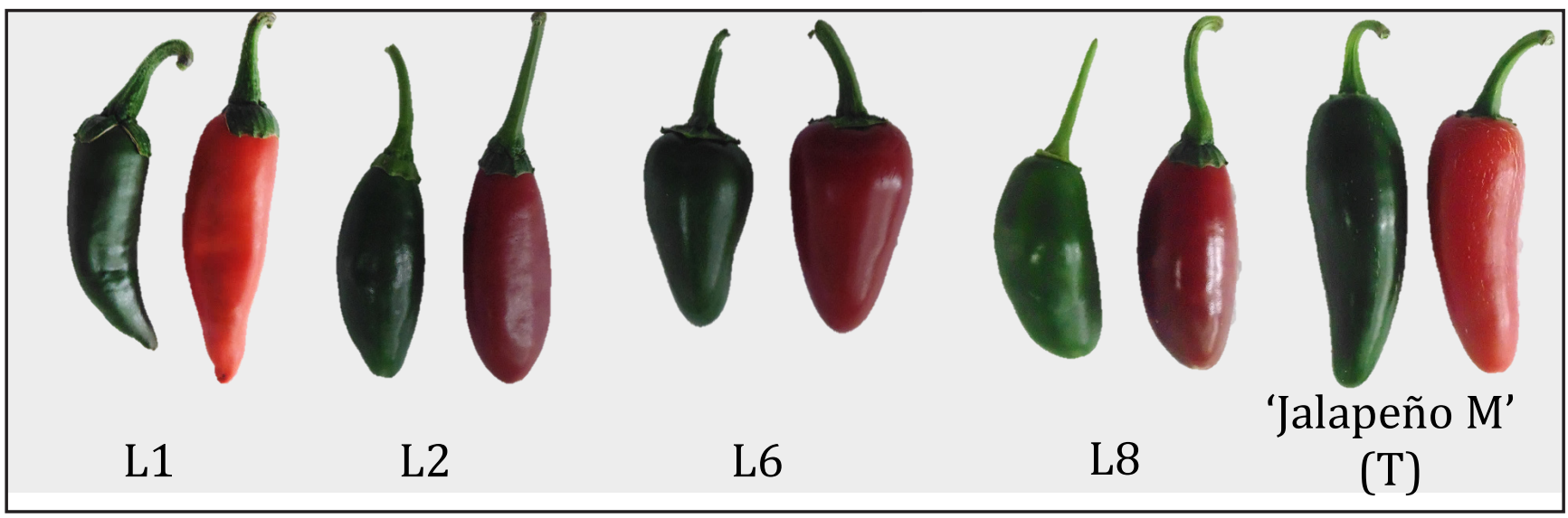

Figure 1. Shape and color of C. annuum fruits evaluated in second DUS test: T= Commercial genotype used as control ('Jalapeño M', oval fruit); Lines candidate for protection: L1 (narrow angular fruit); L2 and L8 (elliptical fruit); L6 (triangular fruit) \{formato e coloração dos frutos de C. annuum var. annuum avaliados no segundo ensaios de DHE, sendo: T= Testemunha ('Jalapeño M', fruto ovalado); Linhagens candidatas à proteção: L1 (fruto estreito angular); L2 e L8 (fruto elíptico); L6 (fruto triangular)\}. Campos dos Goytacazes, UENF, 2014.

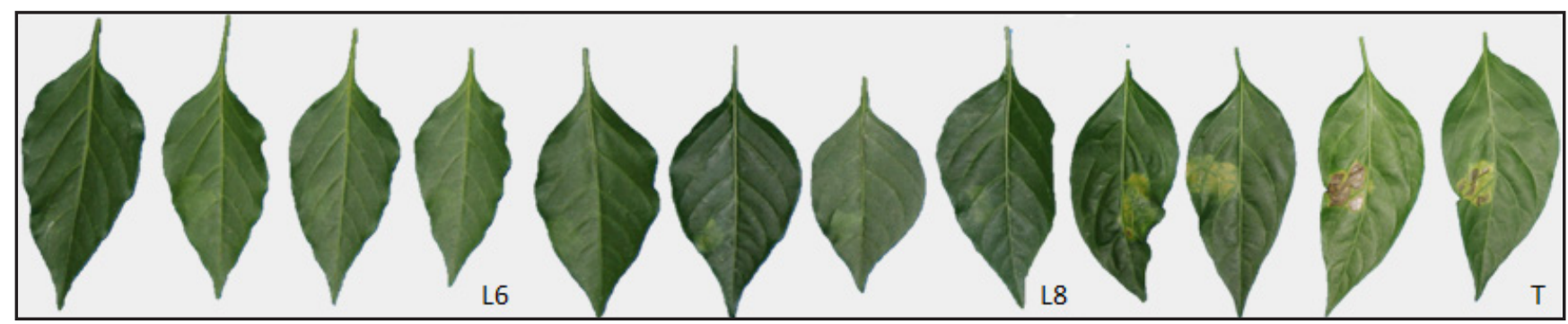

Figure 2. Inoculated leaves of C. annuum var. annuum with Xanthomonas euvesicatoria showing absence of symptoms of bacterial spot (L6 and L8) and symptoms (T), characterizing the resistant and susceptible genotypes, respectively. L6 and L8= lines candidates for protection and T= control ('Jalapeño M') \{folhas de C. annuum var. annuum com ausência de sintomas de mancha bacteriana (L6 e L8) e com sintomas $(\mathrm{T})$, demonstrando a resistência e suscetibilidade, respectivamente. L6 e L8 linhagens candidatas à proteção e T= Testemunha ('Jalapeño M')\}. Campos dos Goytacazes, UENF, 2014.

pepper consumption, less pungent and more aromatic (Henz, 2004), or even with no pungency and typical aroma. In addition to this distinction, there was homogeneity and stability for all evaluated descriptors, which accredits this line as being suitable for protection.

According to Machado (2011), a useful descriptor in DUS tests is one that allows differentiation between candidate genotypes. In this context, 13 descriptors were found to be useful in L8 differentiation (Table 1). Moreover, homogeneity and stability were achieved for this lineage. The descriptors, shape of fruit in longitudinal section (no. 28) and resistance to bacterial spot (no. 49), were important in the differentiation of this lineage compared with 'Jalapeño M'. We noticed the presence of capsaicin (no. 46) within L8 fruits, which is an important attribute in fruit quality and one of the reasons chili peppers are appreciated (Bosland \& Baral, 2007).

Fruit shape, showed by descriptor no. 28 , was very important distinguishing between candidates, being that only L2 and $\mathrm{L} 8$ received the same classification for this trait. The commercial variety was described as oval-shaped fruit, while L1 varied within this descriptor. Considering both tests, the first was classified as elliptical and, in the second, narrow and triangular. On the other hand, L6 was considered triangular while L2 and L8 were elliptical (Figure 1). A striking characteristic of Capsicum pepper fruits is the great variability in shape. This trait as well as others related to the fruit, such as color, texture, brightness and capsaicin presence, are important for the pepper market, because they are the first thing seen by the consumer (Frank et al., 2001; Filgueira, 2012).

Importantly, the added descriptor (no.49), which aims to identify resistance to bacterial spot, became the main descriptor among the evaluated, because it allowed for the differentiation between candidates with control (Figure 2). Recombined lines L1, L2, L6 and L8 obtained values ranging from 1 to 2 , and are considered resistant according to Riva-Souza et al. (2009). In contrast, 'Jalapeño M' reached grade 5, indicating bacterial spot susceptibility. The same result was also observed when considering AUDPC since recombinant lines reached maximum value of 16 and 'Jalapeño M' scored 27 as maximum value. Furthermore, this descriptor alone would differentiate these new genotypes from any other control of the same species, since there are none C. annuum chili pepper plants with this characteristic protected and registered in Brazil to date (Brazil, 2014). Adding disease resistance descriptors in DUS 
testing is allowed as it ensures the consistency of results with the proper use of evaluation methods (Lovato, 2011).

Recombinant lines come from the same two-parent cross and there is a need for morphological trait analysis that would allow for differentiation among them, beyond agronomic characteristics used during the final stages of selection of such lines in the breeding program, as performed by Moreira et al. (2009, 2010). The descriptors used in the DUS tests have enabled to distinguish lines. Only L2 and L8 had the same ratings; therefore, it is not possible to distinguish between them with the descriptors used, although field trials indicate differences between both. Nevertheless, only L8 is able to protection, as L2 did not achieve the required homogeneity. Generally, the main descriptors that proved the difference between lines were shape of fruit in longitudinal and cross section, and the presence or absence of capsaicin in the placenta (Table 1).

Some descriptors were considered somewhat difficult to use as they are entirely dependent on evaluator's interpretation of the proposed classification, for instance, fruit length (no. 26), diameter (no. 27) and pericarp thickness (no. 39). Although they have quantitative aspect influenced by various environmental factors, their evaluation, according to DUS testing standards, requires a qualitative analysis. Observed values should be divided into class intervals; however, the proposed descriptors do not determine any value specification of the metric difference between scores to decide about the different classes observed and to allow the differentiation between genotypes under test. Therefore, classification is left to the discretion of each evaluator and may then be different. Concerning the descriptors related to flowering and ripening crop cycle interval (no. 47), the difference of days can be considered enough to determine whether a plant is early, intermediate or late. In this case, a previous discretion should be established to guide classifications.

An important point to be observed during DUS testing performance is the choice of the control variety, since choosing plants with traits entirely different from pre-candidates cultivars could ensure this protection. In contrast, according to Aviani \& Machado (2011), varieties very similar to those being tested should be chosen as control for DUS comparative trials. Thus, in order to meet this requirement, this study selected a Brazilian registered plant with some similar traits to contemporary candidates. When two lines in test are compared to control plants ('Jalapeño M') about $60 \%$ of the descriptors have the same classification. Currently in Brazil, only two protected chili pepper plants have different traits from those evaluated in this research (Carvalho et al., 2009), however, they are not resistant to bacterial spot, and thus they were not used in this study as controls.

Despite the large number of descriptors required for the protection of Capsicum species, few of them were efficient in distinguishing genotypes of C. annuum var. annuum. Interestingly, these descriptors are useful in checking the similarity between candidates and commercial genotypes. Furthermore, some descriptors, such as no. 15, 17, 18 and 19, would not need to be evaluated when performing DUS tests with genotypes of the $C$. annuum var. annuum, since they should not change as they are typical characteristics to differentiate species.

Another aspect to be considered is the distinctiveness required between lines. Moreover, one point that is not considered by law to protect plants and perhaps the most important in proving distinctiveness is the plant origin. If the lines are derived from a consolidated breeding program, whereby the steps to obtain genotypes are performed correctly, and these lineages will certainly comply with the distinctiveness pattern, i.e., they are distinct new varieties from existing plants. The only exception in this case is related to essentially derived varieties.

Accessibility to information about the protection of plant varieties in Brazil can be considered sufficient from the point of view of people interested in the subject, since clarification on the LPC are well publicized in the MAPA webpage and other specific publications.
In addition, the National Service of Plant Variety Protection is easy to contact, the technical team is helpful, and the information provided is enlightening. Meanwhile, few academic studies report the DUS testing stages for the varied species of agricultural interest, as well as difficulties and hindrances, although there are hundreds of protected plants ranked on MAPA website. Scientific dissemination of this information may be useful to encourage discussion to improve protection procedures, as well as serving to guide the training of breeders.

In this research, after the completion of DUS tests, it was found that L6 and L8, which combine good agronomic traits and resistance to bacterial spot, were eligible for protection, since they were demonstrably distinct, homogeneous, and stable according to the SNPC/MAPA criteria representing new technological products. Despite the fact of being labor-intensive, the DUS testing performance is essential to ensure that only new genotypes are protected, guaranteeing the breeders' rights on new varieties. It is also a protocol to fulfill the breeders' education process, which should be able to generate new products with the potential to be effectively used by farmers.

\section{REFERENCES}

ARAÚJO, JC. 2010. A lei de proteção de cultivares: análise de sua formação e conteúdo. Brasília: Edições Câmara. 137p.

AVIANI, DM; MACHADO, RM. 2011. União internacional para proteção das obtenções vegetais (UPOV). In: Proteção de cultivares no Brasil/Ministério da Agricultura, Pecuária e Abastecimento. Secretaria de Desenvolvimento Agropecuário e Cooperativismo. Brasília: Mapa/ACS. p. 17-22.

BOSLAND, PW. 1996. Capsicums: Innovative uses of an ancient crop. Arlington, VA: ASHS Press. p. 479-487.

BOSLAND, PW; BARAL, JB. 2007. Bhut Jolokia The world's hottest known Chile pepper is a putative naturally occurring interspecific hybrid. HortScience 42: 222-224.

BRASIL. 1997. Decreto-lei 9456 de 28 de abril de 1997. Lei de proteção de cultivares. Diário oficial [da República Federativa do Brasil], Brasília, 28 de abril de 1997, 79: 8241-8246, seção1.

BRASIL. 2006. Ato no. 2 de 22 de março de 2006. Instruções para execução dos ensaios 
de distinguibilidade, homogeneidade e estabilidade de cultivares de pimentão e pimenta (Capsicum spp.). Diário oficial [da República Federativa do Brasil], Brasília, 27 de março de 2006, p. 7, seção 1 .

CAMPBELL, CL; MADDEN, LV. 1990. Introduction to plant disease epidemiology. New York NY: John Wiley \& Sons.

CARVALHO, SIC; BIANCHETTI, LB; REIFSCHNEIDER, FJB. 2009. Registro e proteção de cultivares pelo setor público: a experiência do programa de melhoramento de Capsicum da Embrapa Hortaliças. Horticultura Brasileira 27: 135-138.

FILGUEIRA, FAR. 2012. Novo manual de olericultura: agrotecnologia moderna na produção e comercialização de hortaliças. Viçosa: UFV. 402p.

FRANK, CA; NELSON, RG; SIMONNE, EH; BEHE, BK; SIMONNE, AH. 2001. Consumer preferences for color, price, and vitamin $\mathrm{C}$ content of bell peppers. HortScience 36: 795-800

GILLILAND, TJ; GENSOLLEN, V. 2010. Review of the protocols used for assessment of DUS and VCU in Europe Perspectives. In: Huyghe C. (eds). Sustainable use of genetic diversity in forage and turf breeding. Netherlands: Springer Verlag. p. 261-275.

GREENGRASS, B. 2004. Plant variety protection and the protection of traditional knowledge In: Twarog, S; Kapoor, P (eds). Protecting and promoting traditional knowledge: Systems, national experiences and international dimensions. New York and Geneva: United Nations. p. 135-139.

HENZ, GP. 2004. Perspectivas e potencialidades do mercado de pimentas. Anais do I Encontro Nacional de Agronegócio de Pimentas. Brasília: Embrapa Hortaliças p. 1-8.

ISF. 2012. International Seed Federation. ISF View on Intellectual Property. Disponível em: http://www.worldseed.org/isf/ onintellectualproperty.html.View_on Intellectual_Property_2012(2).pdf. Acessado em 16 de agosto de 2014.

JONES, JB; STALL, RE; BOUZA, RH. 1998. Diversity among Xanthomonas pathogenic on pepper and tomato. Annual Review of Phytopathology 36: 41-58.

LEITE, DS; MUNHOZ, LL. 2013. Biotecnologia e melhoramento das variedades de vegetais: Cultivares e Transgênicos. Veredas do Direito 10: 23-44.

LOVATO, FA. 2011. Uso de características de resistência a doenças em testes de DHE. In: Proteção de Cultivares no Brasil/Ministério da Agricultura, Pecuária e Abastecimento. Secretaria de Desenvolvimento Agropecuário e Cooperativismo. Brasília: Mapa/ACS. p. 147-154.

MACHADO, RZ. 2011. Elaboração de diretrizes de distinguibilidade, homogeneidade e estabilidade (DHE). In: Proteção de cultivares no Brasil/Ministério da Agricultura, Pecuária e Abastecimento. Secretaria de Desenvolvimento Agropecuário e Cooperativismo. Brasília: Mapa/ACS. p. 121-142.

McLEOD, MJ; GUTTMAN, SI; ESHBAUGH, WH. 1982. Early evolution of chili peppers (Capsicum). Economic Botany 36: 361-368.

MOREIRA, SO; ARAÚJO, RRML; SUDRÉ, CP; RIVA-SOUZA, EM. 2009. Desempenho agronômico de linhas endogâmicas recombinadas de pimenta em dois sistemas de cultivo. Ciência Rural 39: 1387-1393.

MOREIRA, SO; RODRIGUES, R; ARAÚJO, ML; RIVA-SOUZA, EM; OLIVEIRA, RL. 2010. Desempenho agronômico de linhas endogâmicas recombinadas de Capsicum annuит em sistema orgânico sob cultivo protegido. Ciência Agrotec 34: 886-891.

QUEZADO-DUVAL, AM; CAMARGO, LEA. 2004. Raças de Xanthomonas spp. associadas à mancha-bacteriana em tomate para processamento industrial no Brasil. Horticultura Brasileira 22: 80-86.

RAMALHO, MAP; TOLEDO, FHRB; SOUZA, JC. 2010. Melhoramento genético de plantas no Brasil. In: RAMALHO, MAP; TOLEDO, FHRB; SOUZA, JC; TEIXEIRA, RA. (eds). Competências em melhoramento genético de plantas no Brasil. Viçosa: Arka. p. 17-37.

RIVA, EM; RODRIGUES, R; PEREIRA, MG; SUDRÉ, CP; KARASAWA, M; AMARAL JUNIOR, AT. 2004. Inheritance of bacterial spot disease in Capsicum annuum. Crop Breeding and Applied Biotechnology 4:490494.

RIVA-SOUZA, EM; RODRIGUES, R; SUDRÉ, CP; PEREIRA, MG; BENTO, CS; MATTA, FP. 2009. Genetic parameters and selection for resistance to bacterial spot in recombinant $\mathrm{F}_{6}$ lines of Capsicum annuum. Crop Breeding and Applied Biotechnology 9: 108-115.

RODRIGUES NETO, J; MALAVOLTA, VA; VICTOR, O. 1986. Meio simples para o isolamento e cultivo de Xanthomonas campestris pv. citri tipo B. Summa Phytopathologica 12: 16.

SANTOS, FS; MACHADO, RZ. 2011. Analisando a estabilidade. In: Proteção de cultivares no Brasil/Ministério da Agricultura, Pecuária e Abastecimento. Secretaria de Desenvolvimento Agropecuário e Cooperativismo. Brasília: Mapa/ACS. p. 183-185.

SANTOS, FS; AVIANI, DM; HIDALGO, JAF; MACHADO, RZ; ARAUJO, SP. 2012. Evolution, importance and evaluation of cultivar protection in Brazil: the work of the SNPC. Crop Breeding and Applied Biotechnology 12: 99-110.

UPOV. 2002. Plants of new varieties of international union for the protection of new varieties of plants. Disponível em: http:// www.upov.int/en/publications/conventions/ 1991/act1991.htm. Acessado em 16 de agosto de 2014.

VIANA, AAN. 2011. A proteção de cultivares no contexto da ordem econômica mundial. In: Proteção de Cultivares no Brasil/Ministério da Agricultura, Pecuária e Abastecimento. Secretaria de Desenvolvimento Agropecuário e Cooperativismo. Brasília: Mapa/ACS. p. 11-16. 